\title{
Time and Timelessness in Constitutional Thought
}

\section{Thomas Poole ${ }^{1}$}

Published online: 10 June 2020

(c) The Author(s) 2020

\begin{abstract}
This paper considers the character of moral peoplehood, our life as a people, and the rules and principles through which that life is expressed. In so far as those rules and principles take legal form, as determining the ground rules of association and denoting political rights and duties, this moral community is also a jural community. The paper engages with Bernard Williams's thought with a view to resolving the tension between two conceptions of the constitution that differ in their account of the relationship between norms and time. Williams offers the prospect of a non-Kantian liberalism that grows out of the habits and minds of persons but which does not collapse into relativism. I argue that Williams's account of moral personhood devotes insufficient attention to the dynamics of moral deliberation, essential to the growth of personhood. I argue that Williams's account of moral peoplehood is similarly deficient in that it overlooks the role constitutional deliberation plays in constructing the jural community. Plural politics requires accepted ground rules and the sense that we are a unity of plural associates, and this is what constitutional deliberation aims to provide.
\end{abstract}

Keywords Bernard Williams $\cdot$ Moral peoplehood $\cdot$ Jural community $\cdot$ Moral sentiments $\cdot$ Constitutional deliberation $\cdot$ Legitimacy

Time means succession, and succession, change:

Hence timelessness is bound to disarrange

Schedules of sentiment.

John Shade (alias Vladimir Nabokov) ${ }^{1}$

1 Nabokov (2001, p. 46).

Thomas Poole

t.m.poole@1se.ac.uk

1 Present Address: Law Department, London School of Economics and Political Science,

Houghton Street, London WC2A 2AE, UK 


\section{Introduction}

The concept of constitution presupposes the idea of moral peoplehood. The very idea of organising political life, our life as a people, within the terms of a more or less settled, more or less agreed-upon framework of institutions, practices and rules depends, that is, on the existence of an association of a certain character. It is an association that understands itself as a singular entity, a collective existing in contradistinction to all others ('The People') (Lindahl 2018). Associates address each other about the terms of their association in a vernacular understood to have developed within the auspices of the association ('We-ness') (Oakeshott 1975). To the extent that those terms of association are understood at least partly in legal terms, as concerning the determination of the ground rules of association, expressed in the language of rights and duties, we might say further that this moral community is also a jural community (Dyzenhaus 2020). A very important subset of this kind of association, an association patterned but not necessarily circumscribed by 'fundamental' or 'basic' laws (White and Ypi 2017), is the constitution.

But associates within such a constitutional practice see that practice as having a continuing history. The community constituted by the ground rules, despite the vagaries of fate, various ups and downs, augmentations and diminutions, is taken to be essentially the same now as before. The association understands itself not just as one, then, but as one in time. This perspective entails that normative reflection-that is, argument about the ground rules of association-takes the shape of a presentfocused inquiry resolvable through the elaboration of arcs of meaning that deploy principled positions from the life of that collective through time. In engaging in this practice we hold simultaneously the belief that 'our era is different from all others' and that 'our own society is intelligible only if we are aware of its origins' (Lefort 1986, 139).

A perennial problem for the study of constitutional practice is the way that this important aspect of associational life presents two seemingly incompatible facets, which I call in this paper 'time' and 'timelessness'. ${ }^{2}$ By time, I mean something like the notion that a constitution exists and can only exist in a concrete spatial-temporal setting, that it is a product of that setting and expresses what the association that inhabits it takes at a given moment to be its basic rules of political association. A constitution, on this reading, is said to have a singular and uniquely situated past, present and (one supposes) future (e.g. Burke 1986; Schmitt 1996). By timelessness, I mean the way a constitution can be understood as transcendent, operating in a sense somehow out of time. ${ }^{3}$ Sustained by the belief that it is meaningful to think about a constitution as existing in a kind of rolling eternal present, and focusing on the argumentative and constructive dimension of the practice, this conception tends

\footnotetext{
${ }^{2}$ Barschack (2009) makes a similar distinction between 'immanent' and 'transcendent' conceptions of the constitution.

3 Another possible meaning of timelessness, namely that the constitution partakes something of the $s u b$ specie aeternitatis - that it ought to be treated as though it exists for ever-is not discussed here, though I suspect it relates to this second conception of constitutions.
} 
to take a strongly normative (and so universalising) cast (e.g. Bentham 1988; Kelsen 1945), often resulting in a relatively thick framework of determinable principles of constitutional justice (e.g. Rawls 1999; Brudner 2004). ${ }^{4}$

This pairing of time and timelessness implicates, if not underlies, a series of dualisms that continue to animate constitutional theorists: change and stability; sentiment and reason; custom and right; practice and principle; fact and norm; the transitory and the transcendent; the crooked and the straight. ${ }^{5}$ Ignoring the last two, rarely spoken about now but which still resonate subliminally, it is common for constitutional thinkers to give more weight to the second of each pairing. The more this is true, and the more weight given to the second over the first, the more decisively we are in the grip of a Kantian picture of constitutional order (e.g. Ripstein 2009).

This paper turns to Bernard Williams for help in navigating the constitutional relationship between time and timelessness. Williams's moral and political thought is distinctive for the attention it gives to the relationship between past and present. One of its more intriguing aspects is how it offers glimpses of a liberalism that is not Kantian but grows out of the habits and minds of persons, and a type of genealogy that does not end in relativism (Williams 2004, pp. 20-40). Such a theory, if it can be identified, might be particularly valuable for constitutional theory. For it seems that, left on their own, each of the views of constitutions mentioned above is unstable. The danger for the first view ('time') is a collapse into conventionalism, with the implication that constitutions are all but reducible to historical accident, accretions of might or fact as opposed to carriers of reason or principle, and the normative claims derive from them merely strategic masks for power games. The danger for the second view ('timelessness') is that, disengaged from material roots (Goldoni and Wilkinson 2018), it can make constitutions seem rootless and arid, with the implication, fatal to a conception that is meant to deliver clear normative propositions, that it lays no non-stipulative claim on $u s$, the agents within the political association who are the addressees of such claims.

The paper begins with Williams's struggle against relativism, part of which is an argument about the past. This introduces us to some of the essential elements of his political theory, but it also provides an opportunity to think about different types of association. I identify a particular variant not properly accounted for by Williams - the contrastive sense of 'we' across time — of which the jural community is an important instance. This becomes the focus of the rest of the inquiry. I turn next to Williams's understanding of moral personhood, focusing on his essay on

\footnotetext{
${ }^{4}$ See Schiavone (2012, pp. 38-39): 'Between nomos and chronos-between rule and time-there was, from the very origins of Western thought, a reciprocal exclusion: the intrinsic vocation of order, its telos, is to halt the process of becoming. If the norm and the rule are perceived as a "revealing of being"-as is stated literally in Plato, and less explicitly but just as forcefully in the Roman jurists ... their dimension is that of unlimited duration, not that of transformation: time is, with respect to them, pure destruction, external and irremediable negativity: this is a familiar theme in the context of a millenarian line of philosophy, from The Republic of Plato to Heidegger's Being and Time.'

5 This opposition goes back a long way. Cicero's political writings were shaped by attention to a similar set of contrary concepts: 'the rational, natural, divine, eternal, and ideally best on one hand, and the human, customary, contingent, historical, particular, and practicable on the other': Atkins (2013, p. 5).
} 
'Moral Luck', part of a sustained critique of Kantianism. Although there is much of value in that paper on moral sentiments, I argue that its account of moral judgement is deficient. What we learn from this interaction is taken into a discussion on moral peoplehood, and more specifically the practice of constitutional deliberation, first by examining the importance of the past for that practice and then by reflecting on its legitimating or membership-reinforcing properties.

\section{The Sense of the Past}

What would Kant do at the Court of King Arthur? So Williams speculates in 'Human Rights and Relativism', an essay that is largely a disquisition on liberal universalism, which he takes to imply the view that if certain human rights exist, they have always existed, and if societies in the past did not recognize them, then that is because either those in charge were wicked, or the society did not, for some reason, understand the existence of those rights' (Williams 2005, p. 67).

Williams's objective is to keep the liberalism but drop the universalism. He also wants to avoid the slide into the position of irony he associates with liberal relativists such as Rorty (e.g. Rorty 1990). The relevant part of the argument begins with a quotation from historian and philosopher R. G. Collingwood: 'We ought not to call [the past] either better than the present or worse; for we are not called upon to choose or to reject it, to like it or dislike it, to approve it or condemn it, but simply to accept it' (Collingwood 1965, p. 85). This is used as a basis from which to attack relativism, the central point being that 'the distinction on which relativism hangs everything, that between "we" and "they", is not merely given, and to erect it a certain point involves a political decision or recognition' (Williams 2005, p. 68).

I agree with that argument. But Williams extends it in this way:

So far as human rights in the contemporary world are concerned, standard relativism is an irrelevance - as it is, in fact, everywhere. The relativism of distance, on the other hand, in many though not all respects, is a sensible attitude to take. It applies to the past (to the extent that it does) for the reason that Collingwood implied, because the past is not within our causal reach. So far as human rights are concerned, what matters is what presents itself in our world, now. In this sense, the past is not another country: if it were just another country, we might have to wonder what to do about it. (Williams 2005, p. 69)

I want to take issue with the argument in this passage, at least if we take it also to apply to constitutions. Leaving aside the parenthetical qualification, which is not clarified, we are presented with an apparent disjuncture between past and present, the point being to isolate the former in our ethical thinking. This abjuration of the historical reoccurs in another essay, 'The Truth in Relativism', where Williams writes that the 'socially and historically remote has always been an important object of self-critical and self-encouraging fantasy'. This is true, but it does not follow either that historically inflected ethical thinking cannot be done proficiently, or that we are even capable of fully expunging the past from our moral and political deliberation. But Williams continues: 'to raise seriously questions in the vocabulary 
of appraisal about this [historical] culture considered as a concrete historical reality will not be possible for a reflective person' (Williams 1981, pp. 141-142; 1986, ch. 9).

The main problem with the argument, as I interpret it, is that it does not really fit what I take to be Williams's general story about the normative development of political associations, which is genealogical, something that takes place across time. This, however, is the focus of a later section. For now, I focus on a more specific criticism, albeit one that opens out into that broader discussion. It is not clear to me that Williams's argument eludes his own criticism of (standard) relativism-that the choice between the 'we' and 'they' is not merely given, and to erect it at a certain point involves a political decision or recognition. It is not clear to me, in other words, that the past is something that we must necessarily abjure on account of it having nothing pertinent to do with the (constitutional) 'we'.

At the very least, the incompleteness of the abjuration argument opens up a space to consider forms of association. In another essay-on Collingwood, as it happens-Williams criticises philosophers, naming Wittgenstein, for 'their evasive use of "we"". To introduce some clarity, Williams distinguishes two types of 'we': the 'inclusive sense', implying 'universalistic preconditions on interpretation and intelligibility'; and the 'constitutive sense, under which "we", here and now, are distinct from others elsewhere and elsewhen, who lived in other and different intelligible human formations' (Williams 2006, p. 358).

But is there not a third relevant meaning of 'we', one which might connect a present us to a past us - and that might even in a certain sense be said to be 'within our causal reach'? Simplifying a little, we might say that the inclusive 'we' equates to all humans, and the contrastive 'we' distinguishes some humans (usually associations) from other humans. Williams assumes that this contrastive sense must denote a 'we' that is of the 'here and now'. But it is common to deploy a variant of this contrastive sense of 'we' and such use seems far from insensible. We find no difficulty talking about 'Manchester United' to mean not just the dull outfit of recent years but also the team of the 1958 Munich air disaster, or the 'Leipzig Gewandhaus Orchestra' that we may have seen Andris Nelsons conduct the other night and the Orchestra in the days when Mendelssohn and Schumann were at the helm. This use of 'we' isor at least can be - of both the here and now, the past and the present.

We might call this variant the contrastive sense of 'we' across time. Williams is content to use it elsewhere. This is not at all surprising once it is accepted that Williams provides a general account of political associations as necessarily and importantly genealogical. In an essay on Nietzsche, 'There are Many Kinds of Eyes', he writes that 'it is a condition of our understanding the future as in a sense our future: it will not be us, but surely we must think of it as the life of people bound to us by the continuation of that narrative' (Williams 2006, p. 330). If it is both possible and meaningful to project a sense of 'we-ness' into the future, which may never come to pass, it must be possible and meaningful to project it backwards into a past that by definition had to have happened.

That being so, perhaps we might think of this contrastive sense of 'we' across time, following Williams's cue, in terms of the distinction between those we take to be inside the narrative and those we take to be outside it - between protagonists and 
others. The types of association to which this sense of 'we' might apply are many and varied, as I have suggested. The interest of this paper lies with jural communities, in which protagonists understand themselves as related through legal ties that encode the community's ground rules of association expressed in the language of rights and duties. Williams tasked the relativists with the thought that the choice between the 'we' and 'they' is not merely given, and to erect it at a certain point involves a political decision or recognition. Applying that thought, we might say that the existence of a jural community is not something given, though it might feel like that, but something that is continually renegotiated and recreated.

\section{The Nature of Moral Personhood}

I want to focus more on this idea of the jural community, a distinctive and important example of the contrastive sense of 'we' across time. I do so first by examining in this section one of Williams's most interesting contributions to moral theory, or more particularly the idea of moral personhood, his paper on 'Moral Luck'.

At the heart of Williams's account of moral personhood is the idea that to be an individual is more than being simply a reasoning apparatus. Each of us is also the main protagonist of a variety of self-authored projects. As he wrote in 'Persons, Character and Morality', 'an individual person has a set of desires, concerns or, as I shall often call them, projects which help to constitute a character' (Williams 1981, p. 5). The projects we self-direct extend backwards and forwards-for the simple reason that they are more than the work of just one day, but also because our choice of current projects is conditioned by the experience of previous projects and framed according to a reflection on the projects we think we might want to pursue at some future point. ${ }^{6}$ These projects are not peripheral to character or ephemeral to the lived life, quite the contrary: "my present projects are the condition of my existence, in the sense that unless I am propelled forward by the conatus of desire, project and interest, it is unclear why I should do on at all' (Williams 1981, p. 12).

This perspective- of the human person understood diachronically, whose capacity to reason develops along the path of its own interaction with the world around it-allows Williams to counter 'the detachment of moral motivations and the moral point of view from the level of particular relations to particular persons' that he associates with Kantianism (Williams 1981, p. 2). Our self-chosen projects shape the development of personhood and in turn help to form the psychological and social matrix in which we judge. Williams thinks that Kantians, by contrast, offer a synchronic and unidimensional model—an image of one's life that seems 'to imply

\footnotetext{
${ }^{6}$ Williams $(1981,10)$ : 'if it is true that this man will change in these ways, it is only by understanding his present projects as the projects of one who will so change that he can understand them even as his present projects'. This idea was more snappily expressed by The Beach Boys when they sang 'Will I dig the same things that turn me on as a kid?/Will I look back and say that I wish I hadn't done what I did?': 'When I Grow Up (To Be a Man)' from Today! (1965).
} 
an external view of one's own life, as something like a given rectangle that has to be optimally filled in' (Williams 1981, p. 12).

Williams develops the position by means of a reflection on moral luck, the salience of which in moral thought is anathema to Kantians, who see one basic form of value, moral value, which is 'unconditioned'. The centrepiece of the essay is the Gauguin story-a stylised version of the artist's decision to go to Tahiti for the sake of his art, leaving his family behind in France. Whether he will in fact succeed cannot be foreseen at the time the decision is taken and first acted upon. Williams uses the story as a means of exploring the intuition that the only thing that might conceivably justify such a choice will be success itself. If the project fails, then Gauguin fails_-not just the Tahiti project, note, but Gauguin the man. But failure may result from different types of bad luck, not all of them relevant to the process of justification. Some luck is extrinsic to his project (e.g. a shipwreck) some intrinsic (e.g. a failure to develop as an artist) but while 'both are necessary for success, and hence for actual justification, but only the latter relates to unjustification' (Williams 1981, p. 26).

Williams draws a sequence of claims out of the Gauguin story. The first is that we are not necessarily in a position to arrive at a full moral judgement at the time of the initial action, but must await the conclusion of the relevant project. 'The justification, if there is to be one, will be essentially retrospective' (Williams 1981, p. 24). Second, this essentially retrospective judgement is itself likely to be coloured to some extent by the outcome of the project. One reason for this is that, when the individual is judging its own actions, "what one does and the sort of life one leads condition one's later desires and judgments. The standpoint of that retrospective judge who will be my later self will be the product of my earlier choices. So there is no set of preferences both fixed and relevant, relative to which the various fillings of my life-space can be compared' (Williams 1981, p. 34). Williams generalises that point to claim, lastly, that 'we can only to a limited extent abstract from the projects and preferences we actually have, and cannot in principle gain a standpoint from which the alternative fillings of our life-rectangle could be compared without prejudice. The perspective of deliberative choice on one's life is constitutively from here' (Williams 1981, p. 35). Williams thinks his approach is a better match with our moral behaviour than the more austere Kantian schema, which he regards as being violently at odds with our sentiments and our view of ourselves (Williams 1981, p. 22).

There is something in this, certainly in the way it accommodates the idea that our moral sentiments can evolve over time, and that the judgements that take place in the web of those sentiments may well be coloured by the outcome of our various projects, the success of which almost invariably depends on generous dollops of (moral) luck. But I want to hone in on the phenomenon of judging, as it remains rather opaque. We can quite easily fit the first two claims - that moral judgement is essentially retrospective and coloured by the outcomes of projects-into a coherent account of judgement. But to say that judgement is retrospective means also that the process of judgement is always ongoing, given that for Williams moral personhood exists in a continuous state of becoming. We arrive at moral judgements in the course of things, accepting at some level that those judgements will remain 
provisional. As Williams says, judgement is always not only 'from here' but also 'from now'?

We can also accommodate the gist of the third claim - that we can only to a limited extent abstract our judging self from our embodied self-into an account of judgement, although it needs repurposing. Even the claim itself, though any more sceptical and it would collapse into the relativism, recognises that some abstraction is essential to moral deliberation. We must at least attempt to step outside ourselves, so to speak, so as to gain the necessary perspective from which to judge ourselves. Adam Smith conjured up the impartial spectator, 'the man within the breast', to describe this phenomenon. ${ }^{8}$ But this is one attempt, one image, among many. The common thread seems to be the ability to isolate a special process (moral deliberation) distinct from the way we process the normal course of events (being and action).

It is here that the idea of an abstract framework consisting of rules and principles comes into its own. The apparent simplicity of this process may gall, as may its apparent rationalism, though given its richness and protean complexity as a matter of practice we remain far from Williams's nightmare of the paint-by-numbers liferectangle. But to be able to judge at all requires, it would seem, a capacity to hold up to our actions something like a looking glass made up of the values that we take to be those of the moral community. ${ }^{9}$ We may have to accept that this is something that we each must fashion to some degree for ourselves-we may even draw pleasure from that fact-and that it is likely to be conditioned by our own experience. But it must be more than the sum of those experiences. If at the moment of moral judgement the looking glass we held up were simply to replay the highlights of our various projects as a narrative thread, it would be inadequate for the purpose.

The dynamics of abstraction and reflection that contribute decisively to the practice of moral judgement may seem an odd facet of human experience, one not straightforwardly reconcilable with our project-driven lives. But to push it too far to the margins would amount to a reduction of the human condition that if acted on would, to invoke Williams against himself, 'involve a vaster reconstruction of our sentiments and our view of ourselves than may be supposed' (Williams 1981, p. 22).

Its importance comes most clearly into focus once we recall that it is an ongoing affair, a more or less continual process of reflection upon our actions and choices as they present themselves to us in our developing lives. For it seems most likely that this iterative cycle of auto-reflection and auto-adjudication is central to the development of moral personhood, and so of what it means to be a person. To call a human being a 'person' is to refer to them as having developed 'a certain conceptual repertoire, character, set of memories, self-image, emotionality, aspirations,

\footnotetext{
7 See my earlier reading of Williams's 'Human Rights and Relativism', where I argue that 'from now' is implicit in 'from here'.

8 'It is reason, principle, conscience, the inhabitant of the breast, the man within, the great judge and arbiter of our conduct ... It is from him only that we learn the real littleness of ourselves, and of whatever relates to ourselves, and the natural misrepresentations of self-love can be corrected only by the eye of the impartial spectator': Smith (1982, III.3.4).

9 David Hume writes that the minds of men are 'mirrors' to each other, reflecting passions back and forth: Hume (2008, T.3.3.2.8).
} 
eccentricities, and so on, all of which are holistically interconnected' (Gillett 1987, p. 80). But instances of self-judgement play a not insignificant role in this development. The element of abstraction required to sustain them means that we become more aware of ourselves as persons - and as curators of our own personhood - at these moments. They are times, not the only times but among the most important, when we more or less self-consciously address ourselves as ourselves.

As Williams's focus on the Gauguin story indicates, there is an inescapably narrative structure to this process of self-constructing personhood. This process plays an important part in my ability to conceive myself as one person, similar in certain respects but ultimately distinct from all others. 'One of the most significant ways in which I treat myself as a person is to talk to and of myself as one' (Harré 1987, p. 103). That we can do this presupposes that the interlocutors (me and myself) share a common story, one that we ourselves have crafted. I talk to myself not simply as though an intimate friend or confidante, but as someone with whom I have been doing this since the start and will be with me at journey's end. These seem to be the conditions for the development of an archetypal property of the human person, the capacity to knit prior experiences and reflections together, building our capacities to do so as we go along, so that we can more ably meet future such experiences and reflections.

\section{The Character of a Jural Community: Time and Timelessness}

The Gauguin story concerns the development of moral personhood. Williams cautions against the straightforward assimilation of morality and politics (e.g. 'Politics and Moral Character' in Williams 1981), but allows for nuanced connections to be drawn between the two (e.g. 'Realism and Moralism in Political Theory' in Williams 2005, pp. 4-6). With care, I see no reason why we cannot approach moral peoplehood, and the idea of jural community, in similar terms. I suggested earlier that the jural community belongs to the category of associations that take the form of contrastive sense of 'we' across time, central to that category being the distinction between those inside the narrative and those outside it, protagonists and others. I suggested that the jural community is distinguished by the legal ties that are taken to constitute the association and that carry structuring rules and normative elements, a basic script of rights and duties, from the association's past through its present into its future. To get closer to the central issue of the paper-the relationship between time and timelessness in constitutional order-I aim to explain how the jural community's concern for its past relates to its basic normative function.

Rather like Gauguin in Williams's story, a political association is more than the sum of its normative parts, important though these are. It sees itself also as having projects-particular instantiations of peace, order, good government, the provision of services and so on-none of which are purely in the here and now (and, incidentally, very few if any now are purely the business of that particular association). It is a type of association that often looks to the past. One reason relates to the development of norms, another to the success of projects. In either case, the engagement is not the same as the one which historians consider themselves to be involved in, 
where the attempt is to understand the past in its own terms. To that extent, Collingwood (and Maitland) are right (Maitland 1911, p. 491). The jural community is the political association reflecting on its basic structuring rules and principles, which include but is not limited to its constitution. When members of that community inquire into the past, they do so in a purposeful and present-oriented way, since they do so with a view to identifying something about the existence, authority, meaning or applicability of a rule or principle. Michael Oakeshott called this type of engagement an inquiry into the legendary past, since it is concerned with identifying prescriptive, authoritative material that carries a message and a moral, distinguishing it from an inquiry into the historical past, which has the past as its exclusive object ('Present, Future and Past' in Oakeshott 1999).

I say something about the historical deliberations of the jural community under conditions of modernity at the end. But now I focus on the general nature of this historical/normative inquiry. I have said so far that the jural community is distinguished by the legal ties that are taken to constitute the association and that form the basic script of rules and principles from the association's past into its future. But that is little more than a soundbite. What we need to work out is the dynamics of this process, and specifically the relationship between the more empirical and more normative elements within it. My starting point in this regard is that if we follow the path Williams takes in 'Moral Luck' we will end up with a position that is mostly time and little timelessness. That is, a conception of moral peoplehood that is strong on situating us within the empirical stew of unfolding events, but weak on how we manage to reflect and take a position on those events and so organise ourselves in those conditions.

I intend instead to repeat the method of the last section, adding to Williams's account a more serious engagement with the practice of judgement. Now, though, the type of reflection we are interested in takes place at the associational level rather than the individual. Typically this will concern the authority, applicability or interpretation of a rule or principle that claims to be dispositive of political rights and duties. I call this a 'constitutional dispute' ${ }^{10}$ and, following Williams, accept that such a dispute can only be determined from here and from now. But in practice we often look for answers to constitutional disputes at least partially by looking to the past, since that is where we take the source of our constitutive rules to lie. ${ }^{11}$ The point of looking back is not to remind ourselves of our earlier projects, successful or otherwise-or not just that. Its primary purpose is to isolate from that mass of old material relevant rules or standards through which the dispute can be argued. To put it in terms used earlier, we in effect fabricate a looking glass made up of the relevant subset of the rules and principles that we take to belong to the jural community.

\footnotetext{
${ }^{10}$ Bear in mind that a constitutional dispute need not be formally about the constitution. The famous English case of Entick $v$ Carrington (1765) 19 Howell's State Trials 1029, argued as a private law matter, though with clear public law elements, would unquestionably count as a constitutional dispute for present purposes.

11 In one sense these rules etc. can only ever exist in the present-they are authoritative only in so far as we believe them to be. But we tell ourselves various origin stories and the like, working in the register of the legendary past, roughly parallel to the way that philosophers the fiction of the state of nature (Williams 2004, ch. 2), as a central part of the legitimation story our political community tells itself.
} 
This is very stylised. We rarely if ever start with a blank sheet. Just as individual moral reflection is ongoing, so too is constitutional deliberation an almost continuous process of addition, subtraction, polishing and refining. That iterative process will almost certainly develop canons of practice, including institutional pathways that denote more or less authoritative or influential contributors. To give some colour to the enterprise, I make two more specific points. The first is that this process of constitutional deliberation can be a significant avenue whereby a political association confronts its past. Not only does the process glean from the association's past self-given standards against which present conduct can be assessed. But that process also involves the association standing in judgement on its own past. In other words, in fashioning quasi-historical tools for present use, constitutional reflection also involves retelling, even reshaping the (legendary) past. ${ }^{12}$ This strong narrative dimension of constitutional politics, which recalls the narrative shaping of moral personhood, is one reason why it tends to be more concerned with the past, via this process of refraction and abstraction, than ordinary politics (Ackerman 1993).

The second point I find more interesting, perhaps because it is somewhat counterintuitive. On my reading of 'Moral Luck', Williams thinks that it is the projects part of human behaviour that is the morally dynamic bit and, in as much as he makes room for it at all, the reflective part the inert. You can see why he would think this, especially given his criticism of Kantianism. By extension, one would expect that it is the projects part of the jural community that produces change within its associational structures, including its constitutive rules and principles. But I do not think that is right. (It is at most half right.) I see the reflective part as the primary site of normative change. Constitutional deliberation is a process of refraction and abstraction that calls on us to examine our past as a source of value. Its essence is active and self-conscious engagement with constitutive rules and principles. This is true even if the result of that process is conservative (Burke 1986). It is not so much the projects themselves that drive normative change ${ }^{13}$ as the process of reconciling those projects with principles of political right. The condition of jural community is a continuous grappling with the 'complex historical deposit' it has been bequeathed (Williams 2005, p. 75).

\section{The Character of a Jural Community: E Pluribus Unum}

One may well ask why we do this. The answer I suspect relates to the idea of membership, or what it means to associate. ${ }^{14}$ We might say that the act of reconciling our current projects with normative commitments sourced from the past in the way I described is at the same time an act of recognising and reinforcing the terms of jural

\footnotetext{
12 One example of this is empire, frequently lauded and generally accepted as legitimate not all that long ago but now far more likely to be judged as misguided or just plain wrong.

13 They cannot — as on their own they constitute 'just one damn thing after another'.

14 Williams would say it is an aspect of the 'legitimation story' that all legitimate government needs. More on this below.
} 
association. Though it can be useful to see it as resting on a social contract, the jural community is not something that can be established in some Hobbesian Big Bang moment and left to its own devices. Just as the human being develops its personhood most during periods of moral reflection, becoming aware of its self and reinforcing capacity for agency by abstracting itself from itself so to speak, so the jural community establishes and re-establishes itself through sustained reflection on the conditions of association. ${ }^{15}$

Williams gives us an insight into the dimension of constitutional deliberation that can reinforce bonds of membership, or at least offers a vocabulary to help describe it. I have talked so far as if he had nothing to say on constitutions, but that is not quite true. He talks briefly about US-style judicial review in his essay 'From Freedom to Liberty: The Construction of a Political Value'. He is somewhat dismissive of the enterprise, arguing that, even if we accept a fairly wide-ranging role for the court, "judicial reasons, the kinds of reason that a constitutional court, however inventive, must attend to, are only one kind of reason' (Williams 2005, p. 87). The bandwidth on which the court operates is too narrow to handle, let alone reconcile, the variety of political disagreements within the modern state.

There may well be some truth in that claim (Waldron 1999). But Williams is wrong to conflate constitutional deliberation with constitutional judicial review. The process is both more wide-ranging and more pervasive than that linkage suggests, though in some instances a court may have a relatively privileged role within it. However, Williams relates his criticism of judicial review to a broader point about political disagreement, a constant theme within his political thought. He argues that 'a rightful claim in liberty implies a juridical authority, of an agreed authority which can rightfully grant or refuse such a claim, and political opponents do not necessarily understand their situation in these terms ... they are not all interpreting the same text' (Williams 2005, p. 86, emphasis added).

If right, this would represent a much bigger challenge. But while I agree with most of the component parts of the claim, I disagree about how those parts should be assembled. I think it is plausible, and perhaps helpful, to see constitutions in terms of a single text or book. ${ }^{16}$ If so, it is meaningful to contrast this realm of the book with the more plural and less normatively constrained, even rumbustious, nature of ordinary politics by describing the latter as a context in which many texts are in play, each vying for authority. For all its detractions, this sort of environment is ultimately a good thing in that it signifies, and probably helps sustain, the availability of a wider range of self-chosen projects (e.g. Dunn 2018). 'We and our political opponents - even our opponents in one polity, let alone those in others-are not just trying to read one text'. Rather, political difference 'is of the essence of politics,

\footnotetext{
15 In 'Realism and Moralism' Williams observes that the solution to the 'first' political question-in Hobbesian terms, the need to secure order, protection, safety, trust, and the conditions of cooperation-is one that is 'required all the time' and is 'affected by historical circumstances': Williams (2005, p. 3).

16 Williams is not the first to have done so: see e.g. Dworkin (1986). In fact, substantial parts of the essay we currently focus on-'From Freedom to Liberty: The Construction of a Political Value' in Williams (2005)—engages with Ronald Dworkin—and also Carl Schmitt (see following note).
} 
and political difference is a relation of political opposition, rather than, in itself, a relation of intellectual or interpretative disagreement'. ${ }^{17}$

Those are the component parts. The picture that emerges in Williams's constellation is of either a marginal role for constitutions, and no meaningful place for constitutional reflection, or else the idea that such reflection occurs during the course of ordinary politics. In relation to the latter reading, it is unclear how and on what terms this might occur. His strong pluralist vision of politics mitigates against sustained engagement with the terms of jural association. What he offers on this front is contingent, and psychological, in its presentation. ${ }^{18}$ On either reading, Williams underestimates the role of constitutional reflection within a functioning political association - underestimates, that is, both its significance and its difficulty.

Reassembling the same component parts can produce a different picture. The obvious rejoinder to Williams would be to emphasise the importance of constitutional reflection for the rule of law. But I run a somewhat different line of attack, more consistent with the argument so far, which connects constitutional deliberation to the idea of membership of a jural community. I want to argue, more specifically, that it is a primary way of understanding ourselves as a political unit, as constituting ourselves as a plural one.

We can accept that ordinary politics is capable of producing laws by which associates can order their projects. We can also accept that while that process is essentially about selecting the policies that are to govern the near future, some consideration of the 'fit' between those policies and the association's past is possible, indeed likely. Perhaps Williams's idea of juridical reason being concerned with the meaning of one text offers a clue to the special function of constitutional deliberation. The reason this one-book metaphor works is not due to side-constraints such as the nature of legal reasoning or the limitations of judicial tribunals, as Williams thought, but goes to the heart of the practice. I have suggested that the ultimate point of constitutional deliberation lies in the attempt to reinforce conditions of jural association. The most basic condition is the existence of one association-an association in the singular, that understands itself as distinct from other similar associations. Only in so far as that condition is fulfilled is it possible for protagonists to recognise each other as associates within one jural community as opposed to a ragbag of disparate factions or partisan groupings.

The point can be made another way. That the object of constitutional deliberation is akin to interpreting one text is the obverse of the fact that jural community involves subjection to one body of law as opposed to many individual laws. The main virtue of this arrangement, from the perspective of those subject to it, is that only under such a structure is it possible to conceive of the judgements that emanate from the public authority as addressing each associate in the same way and

\footnotetext{
17 Williams (2005, p. 78), here finding himself in broad agreement with Carl Schmitt's claim that the fundamental political relation is that of friend and enemy: Schmitt (1996).

18 Williams (2005, p. 86): 'Between opponents who share a polity and neither of whom wants to destroy it, they will agree on an authority or process which decides what will happen, but this is not at all equivalent to the authority's deciding that one or another claim in liberty is rightful'.
} 
with the same voice (Dyzenhaus 2017). There may be a connection here with our earlier analysis of moral personhood, which revealed an iterative process of internal abstraction and reflection important not just for the purpose of moral self-evaluation but also for the construction of our sense of self. We might say, by extension, that the process of constitutional deliberation plays a similar role in the development of moral peoplehood. Constitutional deliberation might focus on the terms of association but it also involves the question of why we associate. It is a context in which a multitude of persons with conflicting projects recognises, in resolving questions that implicate its moral peoplehood, that it is also a unity of associates. It constructs the single public voice by reinforcing its constitutive rules, providing the occasion to reaffirm the sense of inhabiting a collective unit.

How successful this is in practice is a separate matter. Even when it seems to be working, it remains a work in progress-a constitution, after all, is better understood not as a text or thing so much as a skein of jural sentiments, unfolding over time (Poole 2006). But it is interesting that what we have uncovered resembles the idea of the legitimation story (note the singular) that is such an important feature of Williams's political thought. 'For there to be legitimate government, there must be a legitimation story', he argues, 'which explains why state power can be used to coerce some people rather than others and to allow people to restrict other people's freedom in some ways rather than others. Moreover, this story is supposed to legitimate the arrangements to each citizen, that is to say, to each person from whom the state expects allegiance' (Williams 2005, p. 95). That is true. But we have seen that it is highly unlikely that the type of plural politics Williams envisages can produce the single text by means of which such a story can be told. Functioning political association requires something more, something all about our plural one-ness. That is the province of constitutional deliberation.

One last point is in order. Williams writes perceptively on the particularities of modernity. Towards the end of the essay we have been considering he observes that one 'of the most prominent characteristics of modernity is its historical selfconsciousness, and that carries with it certain demands on how we understand ourselves' (Williams 2005, p. 94). This characteristic has implications for constitutional deliberation. Part of what he means by 'awareness' is our reluctance or inability as Moderns to accept religious or other transcendental justifications as part of our legitimation story. This entails, as Williams notes, 'that in telling our own legitimation story we start, in a sense, with less. In interpreting and distributing liberty we allow each citizen a stronger presumption in favour of what he or she certainly wants, to carry out his or her own desires' (Williams 2005, p. 95). It also entails, as Williams does not note, that we are driven to rely still more on constitutional deliberation as a means of generating legitimacy. Modernity makes constitutions vital while making their objectives harder to realise.

Acknowledgements I would like to thank Tatiana Cutts and David Dyzenhaus for their comments on a previous draft.

Open Access This article is licensed under a Creative Commons Attribution 4.0 International License, which permits use, sharing, adaptation, distribution and reproduction in any medium or format, as long as you give appropriate credit to the original author(s) and the source, provide a link to the Creative 
Commons licence, and indicate if changes were made. The images or other third party material in this article are included in the article's Creative Commons licence, unless indicated otherwise in a credit line to the material. If material is not included in the article's Creative Commons licence and your intended use is not permitted by statutory regulation or exceeds the permitted use, you will need to obtain permission directly from the copyright holder. To view a copy of this licence, visit http://creativecommons.org/ licenses/by/4.0/.

\section{References}

Ackerman, Bruce. 1993. We The People: Volume 1-Foundations. Harvard: Harvard University Press. Atkins, Jed. 2013. Cicero on Politics and the Limits of Reason. Cambridge: Cambridge University Press.

Barshack, Lior. 2009. Time and the Constitution. International Journal of Constitutional Law 7: 553-576.

Bentham, Jeremy. 1988. In A Fragment on Government, ed. Ross Harrison. Cambridge: Cambridge University Press.

Brudner, Alan. 2004. Constitutional Goods. Oxford: Oxford University Press.

Burke, Edmund. 1986. Reflections on the Revolution in France. Harmondsworth: Penguin.

Collingwood, R.G. 1965. The Theory of Historical Cycles. In Essays in the Philosophy of History. ed. W. Debbins. Austin: University of Texas Press.

Dunn, John. 2018. Setting the People Free: The Story of Democracy. Princeton: Princeton University Press.

Dworkin, Ronald. 1986. Law's Empire. Harvard: Belknap Press.

Dyzenhaus, David. 2017. Dreaming the Rule of Law. In Law, Liberty and State: Oakeshott, Hayek and Schmitt on the Rule of Law, ed. David Dyzenhaus and Thomas Poole. Cambridge: Cambridge University Press.

Dyzenhaus, David. 2020. The Janus-Faced Constitution. In The Double-Facing Constitution, ed. Jacco Bomhoff, David Dyzenhaus, and Thomas Poole. Cambridge: Cambridge University Press.

Gillett, Grant. 1987. Reasoning about Persons. In Peacock, Arthur and Gillett, Grant. 1987. Persons and Personality. Oxford: Basil Blackwell.

Goldoni, Marco, and Michael A. Wilkinson. 2018. The Material Constitution. Modern Law Review 81: 567-597.

Harré, Rom. 1987. Persons and Selves. In Peacock, Arthur and Gillett, Grant. 1987. Persons and Personality. Oxford: Basil Blackwell.

Hume, David. 2008. A Treatise of Human Nature. In The Clarendon Edition of the Works of David Hume, ed. D.F. Norton and M.J. Norton. Oxford: Oxford University Press.

Kelsen, Hans. 1945. General Theory of Law and State. Trans Anders Wedberg. Harvard: Harvard University Press.

Lefort, Claude. 1986. In The Political Forms of Modern Society: Bureaucracy, Democracy, Totalitarianism, ed. John B. Thompson. Cambridge: MIT Press, Chapter 5.

Lindahl, Hans. 2018. Authority and the Globalisation of Exclusion and Inclusion. Cambridge: Cambridge University Press.

Maitland, Frederic William. 1911. Why the History of English Law is Not Written. In The Colllected Papers of Frederic William Maitland, ed. H.A.L. Fisher. Cambridge: Cambridge University Press.

Nabokov, Vladimir. 2001. Pale Fire. London: Penguin Modern Classics.

Oakeshott, Michael. 1975. On Human Conduct. Oxford: Oxford University Press.

Oakeshott, Michael. 1999. On History and Other Essays. Indianapolis: Liberty Fund.

Poole, Thomas. 2006. Rights and Opinion: Or, The Progress of Sentiments. Law and Ethics of Human Rights 10: 453-478.

Rawls, John. 1999. A Theory of Justice. Oxford: Oxford University Press.

Ripstein, Arthur. 2009. Force and Freedom: Kant's Legal and Political Philosophy. Harvard: Harvard University Press.

Rorty, Richard. 1990. Objectivity, Relativism and Truth: Philosophical Papers. Cambridge: Cambridge University Press.

Schiavone, Aldo. 2012. The Invention of Law in the West. Harvard: Belknap Press. 
Schmitt, Carl. 1996. The Concept of the Political. Trans. George Schwab. Chicago: Chicago University Press.

Smith, Adam. 1982. A Theory of Moral Sentiments. Ed. D.D. Raphael and A.L. Macfie. Indianapolis: Liberty Fund, 1982, Part III, Chapter 1.

Waldron, Jeremy. 1999. Law and Disagreement. Oxford: Oxford University Press.

White, Jonathan, and Lea Ypi. 2017. The Politics of Personhood. Political Theory 45: 439-465.

Williams, Bernard. 1981. Moral Luck: Philosophical Papers 1973-1980. Cambridge: Cambridge University Press.

Williams, Bernard. 1986. Ethics and the Limits of Philosophy. Harvard: Belknap Press.

Williams, Bernard. 2004. Truth and Truthfulness: An Essay on Genealogy. Princeton: Princeton University Press.

Williams, Bernard. 2005. In In the Beginning Was the Deed, ed. Geoffrey Hawthorn. Princeton: Princeton University Press.

Williams, Bernard. 2006. In The Sense of the Past: Essays in the History of Philosophy, ed. Myles Burnyeat. Princeton: Princeton University Press.

Publisher's Note Springer Nature remains neutral with regard to jurisdictional claims in published maps and institutional affiliations. 